\title{
Study of Influence of Cleanliness, Health, Safety \& Environment Sustainability on Tourist to Revisit the Beaches of Indonesia
}

\author{
Gilang Sandhubaya, Syarif Hidayatullah, and Nanny Roedjinandari \\ University of Merdeka Malang
}

Indonesia

\begin{abstract}
Purpose of this study was to determine the effect of cleanliness (cleanliness), health (health), safety (security), environmental sustainability (environmental sustainability) on the interest in visiting again through the intervening variable the satisfaction of the tourists about their interest in tourism destinations Balekambang Beach. Malang Regency and identify the factors that influence cleanliness, health, safety, and environmental sustainability (CHSE). This research approach is quantitative research with descriptive approach study, where the primary data collection method uses the results of interviews with the management of the Balekambang Beach tourism destination, Malang Regency in Sumber Jambe Hamlet in Srigonco Village, Bantur District, Malang Regency, and also giving questionnaires to 100 respondents who was a visitor to Balekambang Beach during the implementation CHSEperiod through the media Google form. While the data analysis in this study using normality test, multicollinearity, heteroscedasticity, autocorrelation, and multiple linear regression test. The results in this study, namely, the variables of cleanliness, health, safety, environmental sustainability, have a positive and significant influence on tourist satisfaction. In contrast, the results for interest in visiting show that the variables safety and health positively influence interest in visiting again. Although this is not the case for the variables of cleanliness and environment sustainability which have a positive but not significant effect on interest in revisiting. So based on these results, it can be studied that tourist satisfaction can mediate the influence between safety and health on interest and revisitingcleanliness and environment sustainability on interest with a note that tourist satisfaction must be guaranteed through increased innovation and quality of destinations in implementing revisiting CHSE. While the factors that influence the management of CHSE are visitor interest in adapting, the environment, the presence of unwanted events. Based on the study results, in practice, this study of the variable CHSE can be a significant innovation in moving the tourism sector in the era of the Covid-19 pandemic in reaching behavioral changes from tourists.
\end{abstract}

Keywords: Cleanliness, Health, Safety, Environment Sustainability, Interest in Visiting, Tourist Satisfaction.

\section{INTRODUCTION}

One of the beach tourism destinations in the Malang Regency area which occupies a priority worth visiting is Balekambang Beach. Balekambang Beach is a beach located in Sumber Jambe Hamlet in Srigonco Village, Bantur District, Malang Regency where the beach has the privilege and attraction of 3 islands around it, the three islands are named Ismoyo Island, Anoman Island, Wisanggeni Island, and the temple on Ismoyo Island which resembles the beauty of Tanah Lot on the island of Bali. According to data obtained based on Perhutani Malang Regency, Balekambang beach, which in 2019 was visited by more than one million tourists, has a target of 1.5 million visits in 2020 or an increase of 500 thousand from the previous target. However, the Coronavirus (COVID-19) outbreak in Indonesia, which also invaded several people in the Malang City and Regency area, has caused the number of foreign tourists entering Indonesia to decline. On the other hand, because the government also stopped flights, which greatly affected the Indonesian tourism sector, this caused many travel and flight companies suffered losses due to the termination of flights. The current condition of the tourism sector with COVID-19 has experienced an extreme sluggishness due to the reduced number of visitors, both local and foreign tourists. It also impacts hotels, tourist attractions, restaurants, and many airports are also closed due to limiting incoming tourists. This causes the country's income and foreign exchange from the tourism sector to decline.

According to data on tourist visits in 2020 at Balekambang Beach, according to data on the 2020-2021 Perhutani entrance fee, previously in January, the monthly visitors reached 52 thousand people, each month decreased, especially in January February which only amounted to 2 thousand visitors. In that month, the issue of Covid-19 was intensively reported on social media the 
mass media. This is not without reason, knowing that fears of contracting the virus have made people reluctant to travel, which other tourism supporting sectors such as food and beverage providers, souvenirssouvenirshas affected and.

The policy of the Indonesian government through the ministries relevant regarding responding to the decline in the number of sector revenues tourism also issued instructions for regions to comply with the protocol standards CHSE. Cleanliness (cleanliness), Health (health), Safety (safety), and Environment Sustainability (environmental sustainability to reduce the number of Covid-19 increases in Indonesia, wherein its implementation, the protocol business actors around the tourism area also followed up CHSE. CHSE Thisitself refers to the operational guidelines from the Decree of the Minister of Health Number HK.01.07/Menkes/382/2020 concerning Health Protocols for the Community in Public Places and Facilities in the Context of Prevention and Control of Coronavirus Disease 2019 (Covid-19) [1], which in addition to being implemented to the private sector business actors in the tourism sector, it is also socialized to Traditional Villages, business and professional associations related to tourist attractions, and Tourism Drive Groups/Tourism Awareness Groups which with their awareness to carry out socialization, tutorials/education, positive aspects which are also focused on this is also intended to min security and increase interest in return visits to related tourism destinations.

Meanwhile, according to Fornell [2] theory, interest in repeat visits is a form of satisfaction that will then encourage subsequent visits, which will then form a sense of loyalty to consumers. Conformity to the needs and product offerings will lead to satisfaction to consumers. Therefore it will lead to consumer repurchase interest in the future [2]. This also stimulates the use of a conceptual basis regarding visitor satisfaction in the implementation of the program CHSE, which is defined as a protocol step or guide to the implementation of cleanliness, health, safety, and environmental sustainability for the creative economy sector, where through a study of satisfaction, the concept of return visits can It is predicted that research on visitor satisfaction and interest can be used as a benchmark to assess the success of implementation revisiting CHSE in the Balekambang Beach destination, Malang Regency and efforts to maximize the quality of Indonesian tourism destinations in the Covid-19 era.

\section{LITERATURE REVIEW}

According to the theory by [3], tourism is the temporary and short-term movement of people to destinations outside the places where they usually live and work and their activities during life in a destination [3]. Meanwhile, according to Mathieson and Wall in [4], tourism is an activity of temporarily moving people to destinations outside their homes and places of work, carrying out activities while at the destination, and preparing facilities to meet their needs [4]. Based on applicable legal regulations and policies, according to Law No. 10 of 2009 concerning tourism, it is stated that the state of nature, flora, and fauna as gifts from God Almighty, as well as historical, artistic, and cultural heritage owned by the Indonesian people, are resources and capital for tourism development to increase the prosperity and welfare of the people as contained in the Pancasila and the Preamble to the 1945 Constitution of the Republic of Indonesia. Thus, the sustainability of the tourism sector is the government's responsibility as an aspect of fulfilling people's welfare.

Meanwhile, in the Covid-19 era, the very relevant concept of measuring the quality of the tourism sector in Indonesia is the principle of management CHSE. CHSE is cleanliness (cleanliness), Health (health), Safety (safety), and Environment Sustainability (environmental sustainability), which guide CHSE has been implemented in the tourism and creative economy sectors in Indonesia since September - October 2020, first applied to the tourism particular interest sector during Covid-19 and continued by other creative sectors where CHSE is shaded by the Decree of the Minister of Health Number HK.01.07/Menkes 328/ 2020 concerning Guidelines for Prevention and Control of Coronavirus Disease 2019 (Covid-19) in Office and Industrial Workplaces in Supporting Business Continuity in Pandemic Situations, as well as Decree of the Minister of Health Number HK.01.07/Menkes 382/2020 concerning Health Protocols for Communities in Places and Facilities General in the Framework of Prevention and Control of Coronavirus Disease 2019 (Covid-19) [1]. The scope of this health protocol includes efforts to prevent and control COVID-19 in public places and facilities by taking into account aspects of individual health protection and critical points in public health protection, involving managers, organizers, or persons in charge of public places and facilities as well as the user community.

Satisfaction of tourism users (tourists) can use a review of the management concept of customer satisfaction. According to the theor, customer satisfaction is the customer's response to the evaluation of - perceivedconformance between prior expectations (or other performance norms) and the actual performance of the product perceived after its use. Meanwhile, according to [5], customer satisfaction is the level of one's feelings after comparing the performance (or results) that one feels compared to his expectations [5]. So that it can be studied that tourist satisfaction is an assessment from customers on the use of goods or services based on the expectations and reality of traveling activities. If consumers feel what they get is lower than 
expected, then the consumer will not be satisfied. Conversely, if what consumers get exceeds what they expect, then consumers will be satisfied. Meanwhile, when what is received is the same as expected, the consumer will feel mediocre or neutral.

Revisiting According to [6] theory, interest is a sense of preference and a sense of attachment to a thing or activity [6]. Meanwhile, according to [7], interest is an unintentional concentration of attention born with complete will and depends on talent and environment [7]. In this case, the theory of revisiting interest is taken from the theory of repurchase interest in a product so that in several categories, visiting interest can be applied to buying interest. Interest is the drive to motivate someone to take action. Where satisfied consumers or customers will make repeat visits in the future and notify others of the perceived service which according to them [8], and [9], explain that the forces that influence buying decisions are classified into two strengths, namely internal strengths such as learning experiences, personality and self-concept, motivation and involvement, attitudes and desires, and external forces such as factors. Cultural, social, environmental, and marketing mix.

\section{RESEARCH CONCEPT FRAMEWORK}

The conceptual framework in this study is the independent variable referring to the implementation of Cleanliness (cleanliness), Health (health), Safety (safety), and Environment Sustainability (environmental sustainability), and the dependent variable, namely Interest in Returning which will be studied using the intervening or mediating variable is Tourist Satisfaction.

Based on the conceptual framework, 13 hypotheses were obtained, namely:

H1. Cleanliness affects Tourist Satisfaction at Balekambang Beach, Malang Regency

H2. Health affects Tourist Satisfaction at Balekambang Beach, Malang Regency

H3. Safety affects Tourist Satisfaction at Balekambang Beach, Malang Regency

H4. Environment Sustainability Affects Tourist Satisfaction at Balekambang Beach, Malang Regency

H5. Cleanliness affects the interest of tourists to visit Balekambang Beach, Malang Regency

H6. Health affects the interest of tourists visiting Balekambang Beach, Malang Regency

H7. Safety affects the interest of tourists to visit Balekambang Beach, Malang Regency

H8. Environment Sustainability affects the interest of tourists to visit Balekambang Beach, Malang Regency

H9. Cleanliness affects Tourists' Revisit Interests Through Tourist Satisfaction at Balekambang Beach, Malang Regency

H10. Health affects Tourists' Revisit Interests Through Tourist Satisfaction at Balekambang Beach, Malang Regency

H11. Safety affects Tourists' Revisit Interests Through Tourist Satisfaction at Balekambang Beach, Malang Regency

H12. Environment Sustainability affects Tourists' Revisit Interests Through Tourist Satisfaction at Balekambang Beach, Malang Regency

H13. Tourist Satisfaction has an effect on Tourists' Revisit Interests at Balekambang Beach, Malang Regency.

\section{METHOD}

\subsection{Research Design The}

The design of this research is quantitative research which is said to be quantitative because the research results are in the form of numbers and analysis using statistics to test hypotheses to determine the relationship between variables. The primary data sources of this study were obtained from respondents. Namely, tourists who visited Balekambang Beach, and secondary data sources were obtained from previous research, literature, and data presented by the parties involved or interrelated in this case, the manager. The instrument of this research is using observation, interviewing the management of Balekambang Beach, Malang Regency, and using a questionnaire with a 5-level Likert scale.

\subsection{Population and Sample The sampling}

Technique in this study is Simple Random Sampling (random sample). The population in this study were all tourists who had and were visiting when the research was conducted. Preliminary observations of the research, precisely as of March 2021, the number of tourist visits ranged from 50 to 100 people per day. While the sample of this study refers to the variable discrete Slovin, which produces a value of 99.98, which is rounded up to 100 respondents from visitors to Balekambang Beach, Malang Regency. 
International Journal of Advances in Scientific Research and Engineering (ijasre), Vol 7 (10), October -2021

\subsection{Variable and Indicator}

Table 1: Variable and Indicator

\begin{tabular}{|c|c|c|}
\hline \multicolumn{2}{|c|}{ Indicator } & \multirow[b]{2}{*}{$\begin{array}{l}\text { Variable andAspect } \\
\text { - } \\
\text { - } \\
\text { - } \\
\text { - } \\
\text { Cleanining of publing sands with soap/hand sanitizer } \\
\text { cleaning fluids is safe and appropriate } \\
\text { - } \quad \text { Vector-free and animals that carry disease } \\
\text { - } \quad \text { Cleaning and equipment for clean toilets Clean } \\
\text { trash can }\end{array}$} \\
\hline Independent & Cleanliness & \\
\hline & Health & $\begin{array}{ll}\text { - } & \text { Availability of hand washing } \\
\text { - } & \text { areas The area has been disinfected Good } \\
\text { - } & \text { MCK facilities }\end{array}$ \\
\hline & Safety & $\begin{array}{ll}\text { - } & \text { Availability of warning signs } \\
\text { - } & \text { Wearing masks } \\
\text { - } & \text { Availability of first aid kits } \\
\text { - } & \text { Availability of a security task force }\end{array}$ \\
\hline & $\begin{array}{l}\text { Environment } \\
\text { Sustainability }\end{array}$ & $\begin{array}{l}\text { - Use of environmentally friendly equipment and materials } \\
\text { - Utilization of water and efficient, healthy energy source in } \\
\text { order to maintain the balance of the ecosystem. } \\
\text { - Waste and liquid waste processing is carried out in a } \\
\text { complete, healthy, and environmentally friendly manner. The } \\
\text { surrounding } \\
\text { - environment is beautiful and comfortable, either naturally or } \\
\text { by technical engineering. } \\
\text { Monitoring and evaluation of the application of electricity } \\
\text { Guidelines and SOPs for the Implementation of Hygiene, } \\
\text { Health, Safety, and Environmental Sustainability. }\end{array}$ \\
\hline $\begin{array}{l}\text { Intervening/Mediating } \\
\text { Tourist }\end{array}$ & $\begin{array}{l}\text { Satisfaction } \\
\text { Tourist } \\
\text { Satisfaction }\end{array}$ & $\begin{array}{l}\text { - Plans to revisit } \\
\text { - Transactional Interests, namely a person's tendency to buy a } \\
\text { product } \\
\text { - Interest Referral, namely a person's tendency to refer a } \\
\text { product to someone }\end{array}$ \\
\hline Dependent & Visiting Interest & $\begin{array}{ll}\text { - } & \text { Loyalty } \\
\text { - } & \text { Word of mouth } \\
\text { - } & \text { Overall Satisfaction }\end{array}$ \\
\hline
\end{tabular}

\section{RESULT AND DISCUSSION}

\subsection{Validity and Reliability}

Test Validity test was carried out on 20 respondents so that the $\mathrm{r}$ table (product-moment) was 0.444 with a significance level of $5 \%$. Based on the tests conducted, the reliability coefficient value is more significant, with the highest value on the Cleanliness variable 0.864 and the lowest value on the Health Variable 0.762. In conclusion, all statement items can be declared reliable with decisions that can distribute questionnaires to the next stage. 
International Journal of Advances in Scientific Research and Engineering (ijasre), Vol 7 (10), October -2021

5.2.1 Normality Test

Table 2: Normality Test Results

\begin{tabular}{|l|l|l|l|}
\hline Model & Test statistics & Sig. & Description \\
\hline Sub Structure 1 & 0.058 & 0.200 & normally distributed Residual \\
\hline 2Substructure & 0.089 & 0.051 & Residualnormal distribution \\
\hline
\end{tabular}

Source: Primary Data Processed, 2021

According to the table (2), it can be seen the significant value of the Kolmogorov Smirnov test results on both models substructure less than 0.05 so that it can be concluded that residuals are normally distributed. Based on these results, it can be concluded that the model formed has met the assumption of normality.

\subsubsection{Multicollinearity Test}

Table 3: Multicollinearity Test Results of

\begin{tabular}{|l|l|r|c|}
\hline \multicolumn{2}{|c|}{ Model } & Collinearity Statistics \\
\cline { 3 - 4 } \multicolumn{2}{|c|}{} & Tolerance & VIF \\
\hline \multirow{1}{*}{1} & (Constant) & & \\
\cline { 2 - 4 } & Cleanliness (X1) & 0.669 & 1.495 \\
\cline { 2 - 4 } & Health (X2) & 0.539 & 1.854 \\
\cline { 2 - 4 } & Safety (X3) & 0.614 & 1.628 \\
\cline { 2 - 4 } & Environment Sustainability (X4) & 0.696 & 1.436 \\
\hline 2 & cleanliness (X1) & 0.614 & 1.628 \\
\cline { 2 - 4 } & Health (X2) & 0.510 & 1.961 \\
\cline { 2 - 4 } & Safety (X3) & 0.575 & 1.741 \\
\cline { 2 - 4 } & Environment Sustainability (X4) & 0.625 & 1,599 \\
\cline { 2 - 4 } & satisfaction (Y1) & Tourist0,445 & 2,245 \\
\hline
\end{tabular}

Based on table (3), thevalue tolerance for substructure model 1 and substructure model 2 has a value of more than 0.10 for all independent variables. Meanwhile, the value of VIF in the substructure model 1 and substructure model 2 has a value of less than 10. Based on these results, it can be concluded that the model formed does not occur in cases of multicollinearity.

\subsubsection{Heteroscedasticity Test}

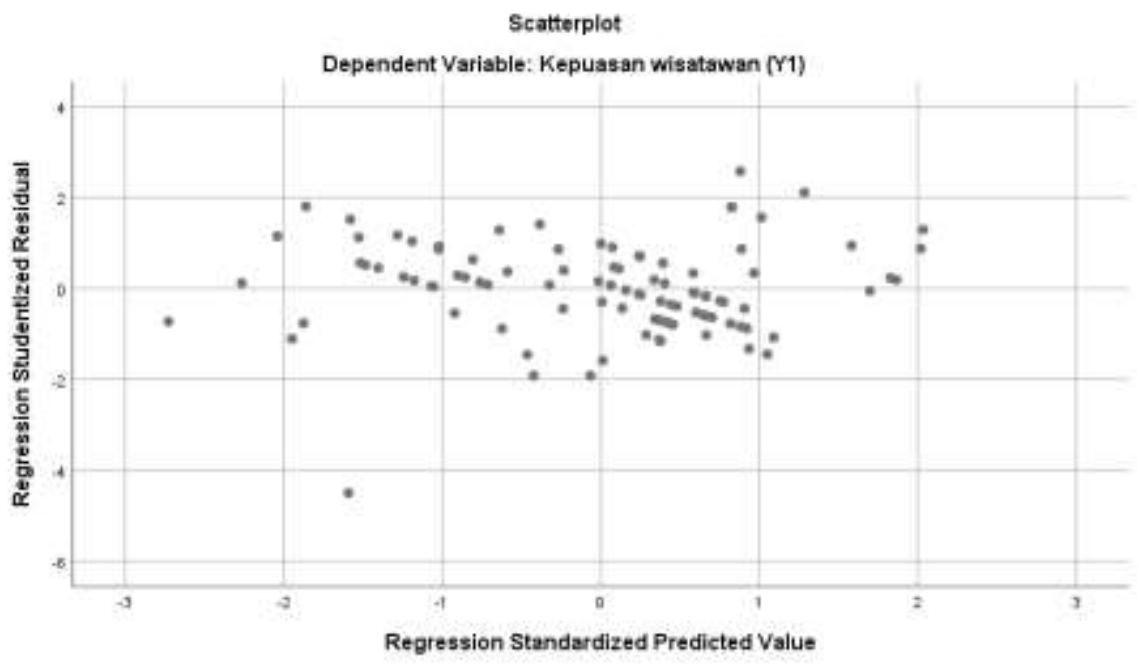

Figure 1: Heteroscedasticity Test Results Substructure Model 1 


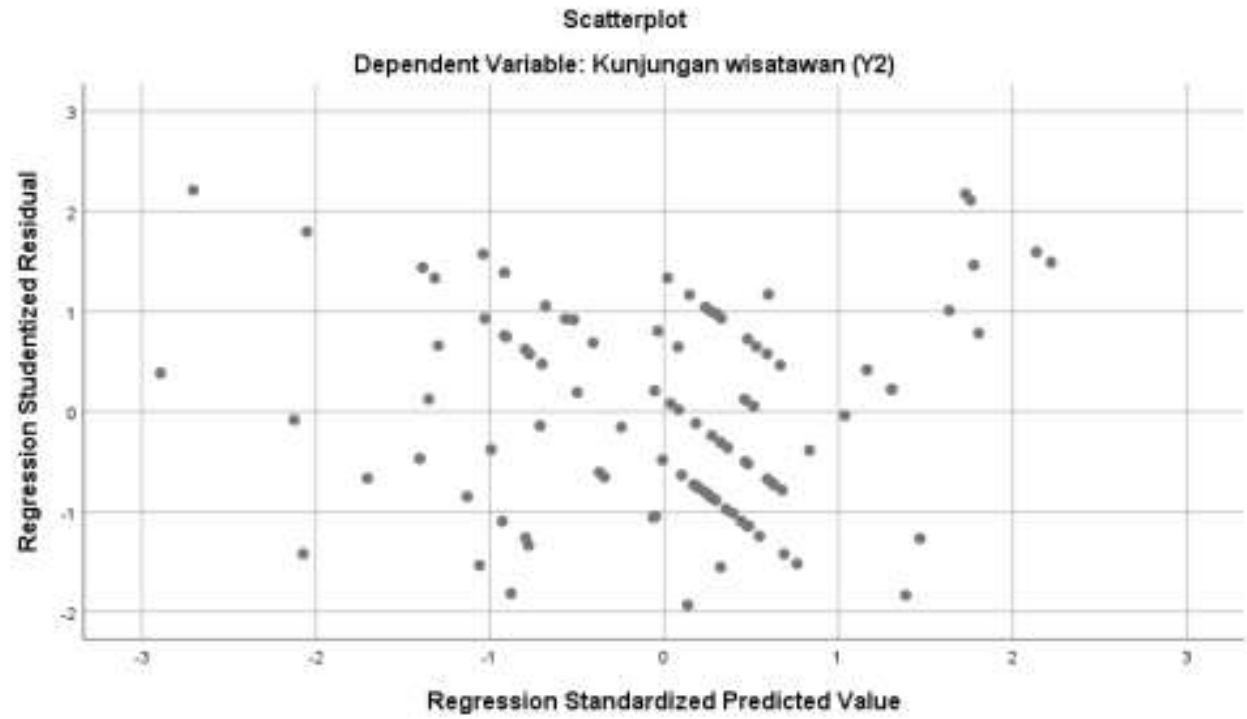

Figure 2: Heteroscedasticity Test Results Substructure Model 2

Based on the results of thegraphs scatter plot in Figure 2 and Figure 4 it can be seen that the observation points are spread out and do not have a certain pattern. In addition, the observation points also spread above and below zero on the y-axis. Based on these results, it can be concluded that the model formed does not occur in cases of heteroscedasticity.

\subsubsection{Autocorrelation Test}

Table 34: Test Results Run Test

\begin{tabular}{|c|c|c|c|}
\hline Model & Test statistics & Sig. & Description of \\
\hline Sub Structure 1 & $-1,608$ & 0.108 & There is no autocorrelation \\
\hline Substructure 2 & -0.804 & 0.421 & There is no autocorrelation. \\
\hline
\end{tabular}

Based on table 4, it can be seen that the significance value of the run test test results is more than 0.05 . So it can be concluded that the model does not occur in cases of autocorrelation. Based on these results, it can be concluded that the model formed has met the assumption of autocorrelation.

Based on the calculation of the combined R Square value above, a value of 0.588 was obtained. This means that all independent variables in the study can explain the two dependent variables by $58.8 \%$ while the rest is explained by other variables outside the model. The combined R Square value of 0.588 is chested above the cut off 0.40so that the model formed has met therequirements Good fit.

\subsection{Path Analysis Test}

5.3.1. Multiple Linear Regression Analysis

Table 5: Multiple Linear Regression Analysis Model I

\begin{tabular}{|c|c|c|c|c|c|c|c|c|}
\hline \multicolumn{9}{|c|}{ Model Summary } \\
\hline \multicolumn{2}{|c|}{ Model } & $\mathrm{R}$ & R Square & \multicolumn{2}{|c|}{ Adjusted R Square } & \multicolumn{3}{|c|}{ Std. Error of the Estimate } \\
\hline \multicolumn{2}{|c|}{1} & $.745^{\mathrm{a}}$ & .555 & \multicolumn{2}{|r|}{.536} & \multicolumn{3}{|c|}{2.3956} \\
\hline \multicolumn{9}{|c|}{ a. Predictors: (Constant), Environment Sustainability (X4), Cleanliness (X1), Safety (X3), Health (X2) } \\
\hline \multicolumn{9}{|c|}{ Coefficients $^{\mathrm{a}}$} \\
\hline \multirow{2}{*}{\multicolumn{4}{|c|}{ Model }} & \multicolumn{2}{|c|}{$\begin{array}{c}\text { Unstandardized } \\
\text { Coefficients }\end{array}$} & $\begin{array}{l}\text { Standardized } \\
\text { Coefficients }\end{array}$ & \multirow[b]{2}{*}{$\mathrm{t}$} & \multirow[b]{2}{*}{ Sig. } \\
\hline & & & & $\mathrm{B}$ & Std. Error & Beta & & \\
\hline \multirow[t]{2}{*}{1} & \multicolumn{3}{|c|}{ (Constant) } & 3,588 & 3,218 & & 1,115 & .268 \\
\hline & \multicolumn{3}{|c|}{ Cleanliness .201.069.244 } & & & (X1) & 2,914 & .004 \\
\hline
\end{tabular}


International Journal of Advances in Scientific Research and Engineering (ijasre), Vol 7 (10), October -2021

\begin{tabular}{|l|l|r|r|r|r||}
\hline Health .337.144.219 & & $(\mathrm{X} 2)$ & 2,346 & .021 \\
\hline Safety .240.094.012 & & .224 & 2,562 & $(\mathrm{X} 3$ \\
& & $(\mathrm{X} 4)$ & 3,288 & .001 \\
\hline $\begin{array}{l}\text { environment Sustainability .272.083 } \\
.270\end{array}$ & & & \\
\hline \multicolumn{2}{|l|}{ Dependent Variable: Tourist satisfaction (Y1) } \\
\hline
\end{tabular}

From the table above, it can be seen that the value of $\mathrm{r}$ square contained in the Summary Model is 0.555 , this shows that the contribution or contribution of the influence of the $\mathrm{X}$ variable to $\mathrm{Y} 1$ is $55.5 \%$ while the remaining $44.5 \%$ is the contribution of the variable others that were not included in the study.

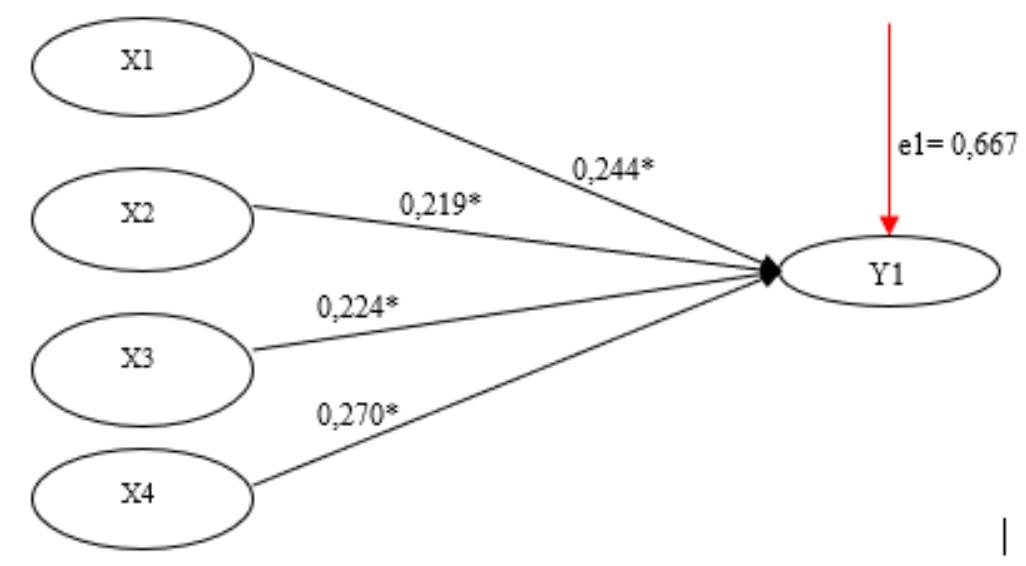

Figure 3: Pathway I Equation Model

Table 6: Results of hypothesis testing of substructure model I

\begin{tabular}{|l|c|c|c|c|c|}
\hline \multicolumn{1}{|c|}{ Effect betweenvariables } & $\begin{array}{c}\text { Standardized Coef. } \\
\text { Beta }\end{array}$ & SE & t & Sig. & Description \\
\hline $\begin{array}{l}\text { Cleanliness }(\mathrm{X} 1) \rightarrow \text { Satisfaction rating } \\
\left(\mathrm{Y}_{2.914}\right.\end{array}$ & 0.244 & 0.069 & $1)$ & 0.004 & Received \\
\hline $\begin{array}{l}\text { Health }(\mathrm{X} 2) \rightarrow \text { Satisfaction rating }\left(\mathrm{Y}_{0.219}\right. \\
0.144 \text { 2.346 }\end{array}$ & & & $1)$ & 0.021 & Received \\
\hline $\begin{array}{l}\text { Safety }(\mathrm{X} 3) \rightarrow \text { Satisfaction rating } \\
\left(\mathrm{Y}_{0.2242 .562}\right.\end{array}$ & & 0.094 & $1)$ & 0.012 & Received \\
\hline $\begin{array}{l}\text { Environment Sustainability }(\mathrm{X} 4) \\
\rightarrow \text { satisfaction }\left(\mathrm{Y}_{1}\right)\end{array}$ & 0.270 & 0.083 & Tourist3,288 & 0.001 & Accepted \\
\hline \begin{tabular}{l} 
Adjusted $R$ Square $: 0.536$ or $53.6 \%$ \\
\hline
\end{tabular}
\end{tabular}

The results of hypothesis testing on the substructure model I obtained an interpretation that for thevariable Cleanliness (X1) on tourist satisfaction $\left(\mathrm{Y}_{1}\right)$, the t-count value of 2.914 is greater than the t-table (1.985) and the significance value (0.004) is less than the $5 \%$ alpha level so that thehypothesis alternativeis accepted, and the t-count value for Health is 2.346 greater than the t-table (1.985) and the significance value (0.021) is less than the 5\% alpha level so that thehypothesis alternativeis accepted, then thet value is Safety2.562 which is greater than the t table (1.985) and the significance value (0.012) is less than the 5\% alpha level $\mathrm{s}$ so that thehypothesis alternativeis accepted, and the $\mathrm{t}$ value for Environment Sustainability is 3.288 which is greater than the $\mathrm{t}$ table (1.985) and the significance value (0.001) is less than the $5 \%$ alpha level so that thehypothesis alternativeis accepted. So it can be concluded that Cleanliness, Health, Safety, Environment Sustainability have a positive and significant influence on tourist satisfaction.

Table 7, Multiple Linear Regression Analysis Model II 
International Journal of Advances in Scientific Research and Engineering (ijasre), Vol 7 (10), October -2021

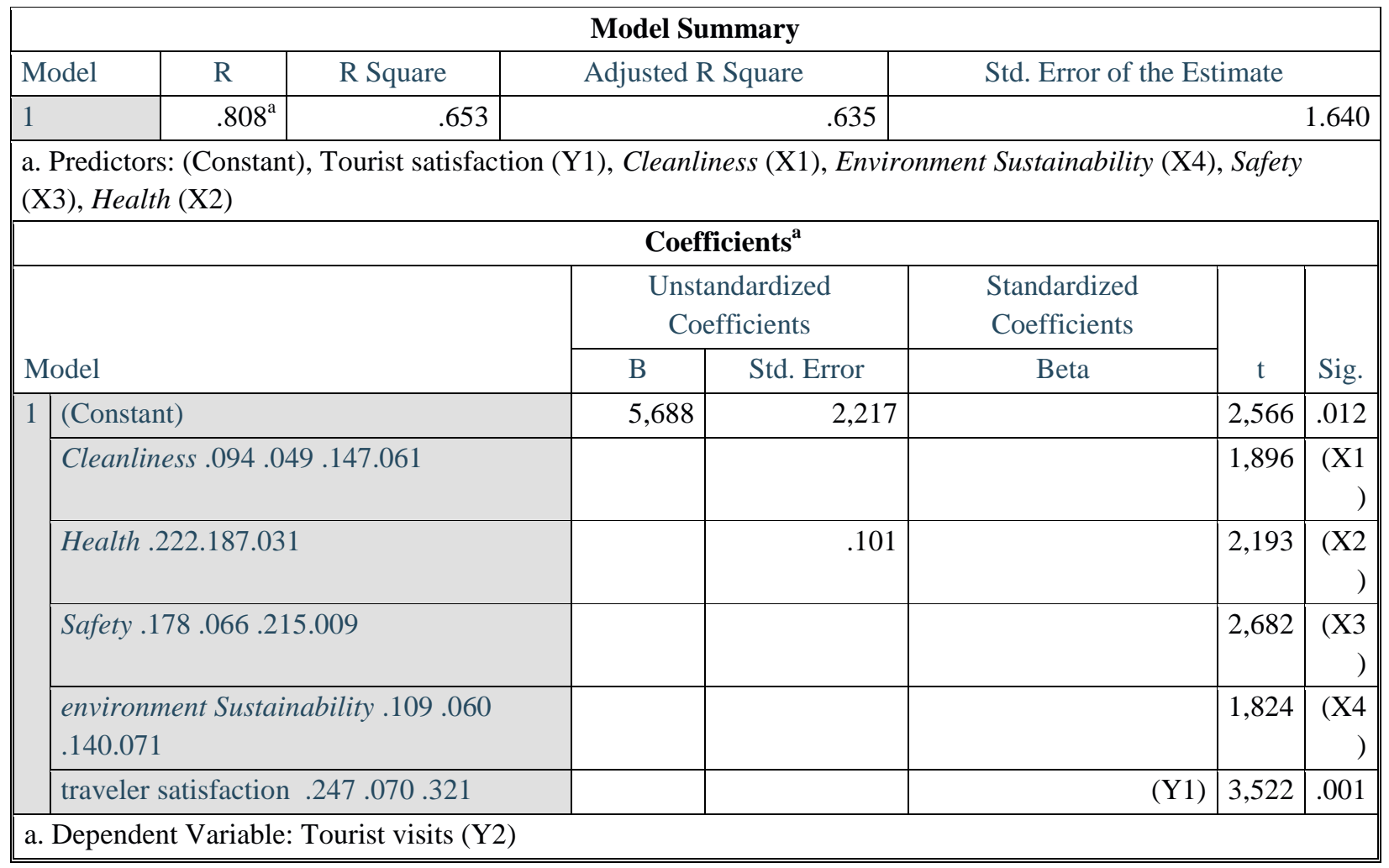

From the table above it can be seen that the value of $\mathrm{r}$ square contained in the Summary Model is 0.653 , this shows that the contribution or contribution of the influence of the $\mathrm{X}$ variable to $\mathrm{Y} 2$ is $65.3 \%$ while the remaining $34.7 \%$ is the contribution of the variable others that were not included in the study.

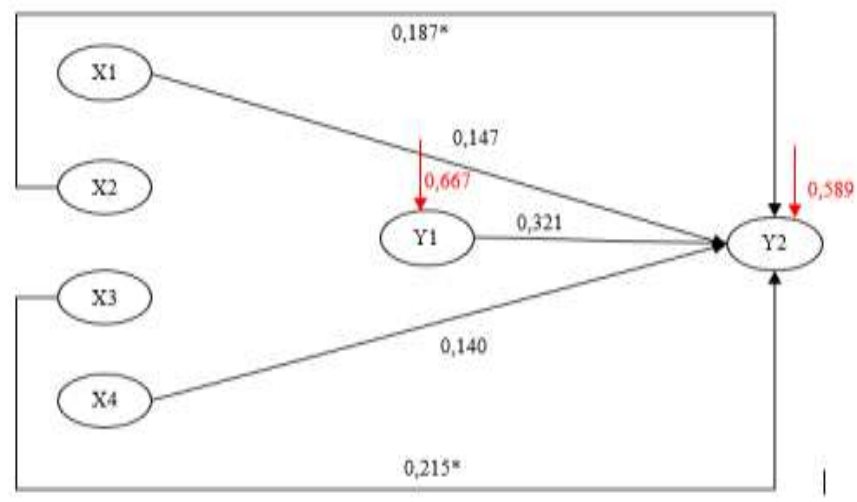

Figure 4: Pathway II Equation Model

Table 8: Results of hypothesis testing of substructure model II

\begin{tabular}{|l|c|c|c|c|c|}
\hline \multicolumn{1}{|c|}{ Effect betweenvariables } & Standardized Coef. Beta & SE & $\mathbf{t}$ & Sig. & Description \\
\hline Cleanliness $(\mathrm{X} 1) \rightarrow$ Interests Been Back (Y2) & 0.147 & 0.049 & 1.896 & 0.061 & Rejected \\
\hline Health $(\mathrm{X} 2) \rightarrow$ Interests Been Back (Y2) & 0.187 & 0.101 & 2.193 & 0.031 & Received \\
\hline Safety $(\mathrm{X} 3) \rightarrow$ Interests Been Back (Y2) & 0.215 & 0.066 & 2.682 & 0.009 & Received \\
\hline $\begin{array}{l}\text { Environment Sustainability }(\mathrm{X} 4) \rightarrow \text { Interests Been } \\
\text { Back }(\mathrm{Y} 2)\end{array}$ & 0.140 & 0.060 & 1.824 & 0.071 & Rejected \\
\hline $\begin{array}{l}\text { traveler satisfaction }\left(\mathrm{Y}_{1)} \rightarrow \text { Interests Been Back }\right. \\
(\mathrm{Y} 2)\end{array}$ & 0.321 & 0.070 & 3.522 & 0.001 & Received: \\
\hline Adjusted $R$ Square 0.635 or 63.5\% & & & & \\
\hline
\end{tabular}

Results of hypothesis testing on the model substructures The second interpretation is that thevariable Cleanliness (X1) has a t-count value of 1.896 which is smaller than the t-table (1.985) and the significance value $(0.061)$ is more than the $5 \%$ alpha 
level so that thehypothesis alternativeis rejected so that Cleanliness (X1) has a positive influence on Interest in(Y2) but the effect is not significant, then thetvalue Health revisitingcalculatedof 2.193 is greater than the table (1.985) and the significance value (0.031) ang from the alpha level of 5\% so that thehypothesis alternativeis accepted, and Safety, namely the t-count value of 2.682 is greater than t-table (1.985) and the significance value (0.009) is less than the 5\% alpha level so that thehypothesis alternativeis accepted, and the t-count value is 1.824 smaller than $t$ table (1.985) and the significance value $(0.071)$ is more than the $5 \%$ alpha level so that thehypothesis alternativeis rejected, which means that Environment Sustainability (X4) has a positive effect on revisit interest (Y2) but the effect is not significant. Then the effect of variables Satisfaction rating ( ${ }_{1)}$ of the Interests Been Back (Y2) obtained coefficient standardized by 0.321 with t 3.532 and significance of 0.001 where t value of 3.532 is greater than t table (1.985) and a significant value (0.001) less from the $5 \%$ alpha level so that thehypothesis alternativeis accepted. It can be concluded traveler satisfaction variable ( $\mathrm{Y}_{1)}$ have a significant positive influence on the Interests Been Back (Y2).

\subsubsection{Path Analysis}

Figure 5: Path Analysis

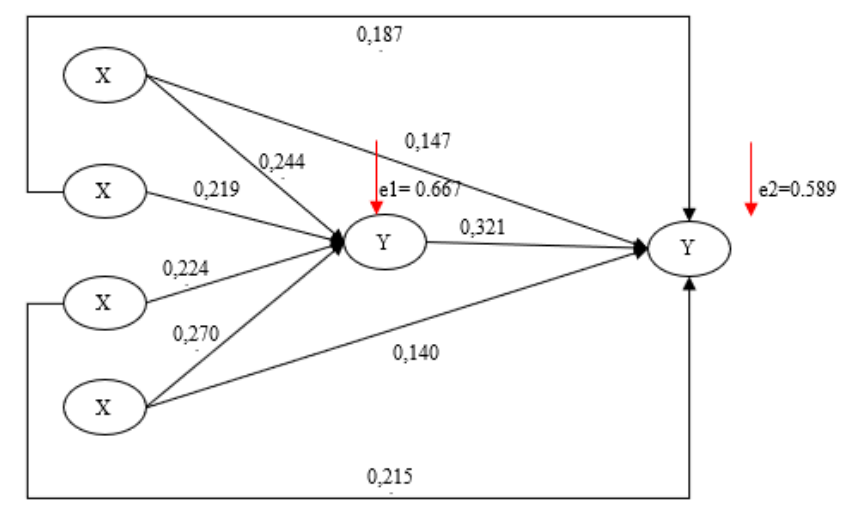

Table 9: The results of the coefficient values of direct influence, indirect effect, and total effect

\begin{tabular}{|c|c|c|c|c|c|c|}
\hline No. & Variable & $\begin{array}{l}\text { influence } \\
\text { Direct }\end{array}$ & influence Indirect & effect Total effect & $\mathbf{t}$ & Conclusion \\
\hline 1 & $\mathrm{X} 1 \rightarrow \mathrm{Y} 1$ & 0.244 & - & 0.244 & 2,914 & sig \\
\hline 2 & $\mathrm{X} 2 \rightarrow \mathrm{Y} 1$ & to 0.219 & & 0.219 & 2,364 & sig \\
\hline 3 & $\mathrm{X} 3 \rightarrow \mathrm{Y} 1$ & to 0.224 & & 0.224 & 2,562 & sig \\
\hline 4 & $\mathrm{X} 4 \rightarrow \mathrm{Y} 1$ & to 0.270 & & 0.270 & 3,288 & sig \\
\hline 5 & $\mathrm{X} 1 \rightarrow \mathrm{Y} 2$ & & & $0.147-0147$ & 1,896 & No sig \\
\hline 6 & $\mathrm{X} 2 \rightarrow \mathrm{Y} 2$ & & & $0.187-0187$ & 2,193 & sig \\
\hline 7 & $\mathrm{X} 3 \rightarrow \mathrm{Y} 2$ & to 0215 & & 0.215 & 2682 & sig \\
\hline 8 & $\mathrm{X} 4 \rightarrow \mathrm{Y} 2$ & 0.140 & - & 0.140 & 1.824 & No sig \\
\hline 9 & $\begin{array}{c}\mathrm{X} 1 \rightarrow \mathrm{Y} 1 \rightarrow \\
\mathrm{Y} 2\end{array}$ & - & $\begin{array}{c}0.244 \times 0.321= \\
0.078 *\end{array}$ & $0.147+0.078=0.225$ & 2.800 & No sig \\
\hline 10 & $\begin{array}{c}\mathrm{X} 2 \rightarrow \mathrm{Y} 1 \rightarrow \\
\mathrm{Y} 2\end{array}$ & - & $\begin{array}{c}0.219 \times 0.321= \\
0.070^{*}\end{array}$ & $0.187+0.070=0.257$ & 1444 & Not sig \\
\hline 11 & $\begin{array}{c}\mathrm{X} 3 \rightarrow \mathrm{Y} 1 \rightarrow \\
\mathrm{Y} 2\end{array}$ & - & $0.224 \mathrm{x}$ & $\begin{array}{c}0.321=0.072 * 0.224+ \\
0.072=\end{array}$ & & No sig \\
\hline 12 & $\begin{array}{c}\mathrm{X} 4 \underset{\mathrm{Y} 2}{\mathrm{Y} 1} \rightarrow \mathrm{C} \\
\mathrm{Y}\end{array}$ & - & $0,270 \mathrm{x}$ & $\begin{array}{c}0.321=0.087 * 0.140+ \\
0.087=\end{array}$ & & No sig \\
\hline 13 & $\mathrm{Y} 1 \rightarrow \mathrm{Y} 2$ & 0.321 & - & 0.321 & 3.552 & sig \\
\hline
\end{tabular}


1. Hypothesis 1 Effect of Variable Cleanliness (X1) to traveler satisfaction (Y1) t value of 2.914 is greater than $\mathrm{t}$ table (1.985) and a significant value (0.004) is less than $5 \%$ alpha level so that the first hypothesis is accepted. So it can be concluded that thevariable Cleanliness (X1) has a positive and significant influence on tourist satisfaction (Y1).

2. Hypothesis 2 Effect of Variable Health $(\mathrm{X} 2)$ to traveler satisfaction $\left(\mathrm{Y}_{1}\right.$ The value of $\mathrm{t}$ count equal to 2,346 bigger than $\mathrm{t}$ table (1.985) and a significant value (0.021) is less than $5 \%$ alpha level so that thehypothesis alternative is accepted. So it can be concluded that thevariable Health (X2) has a positive and significant influence on tourist satisfaction (Y1).

3. Hypothesis 3 Effect of Safety Variable (X3) on Tourist Satisfaction (Y1) The t-count value of 2.562 is greater than the ttable (1.985) and the significance value (0.012) is less than the $5 \%$ alpha level so that hypothesis 4 (H4) is accepted. So it can be concluded that the Safety variable (X3) has a positive and significant influence on tourist satisfaction (Y1).

4. Hypothesis 4 Effect of Environment Sustainability Variable (X4) on Tourist Satisfaction (Y1)

The $t$-count value is 3,288 which is greater than the table (1.985) and the significance value (0.001) is less than the 5\% alpha level so that the alternative hypothesis is accepted. So it can be concluded that the Environment Sustainability variable (X4) has a positive and significant influence on tourist satisfaction (Y1).

5. Hypothesis 5 The Effect of Cleanliness Variable (X1) on Tourists Revisit Interest (Y2)

The calculated $t$ value of 1.896 is smaller than the $t$ table (1.985) and the significance value (0.061) is more than the $5 \%$ alpha level so that hypothesis 5 (H5) is rejected. So it can be concluded that the Cleanliness variable (X1) has a positive influence on revisit interest (Y2) but the effect is not significant.

6. Hypothesis 6 Effect of Health Variable (X2) on Revisit Interest (Y2)

The calculated $t$ value of 2.193 is greater than the t table (1.985) and the significance value $(0.031)$ is less than the $5 \%$ alpha level so that hypothesis 6 (H6) is accepted. So it can be concluded that the Health variable (X2) has a positive and significant influence on revisit interest (Y2).

7. Hypothesis 7 Effect of Safety Variable (X3) on Revisit Interest (Y2)

The t-count value of 2.682 is greater than the t-table (1.985) and the significance value $(0.009)$ is less than the $5 \%$ alpha level so that hypothesis 7 (H7) is accepted. So it can be concluded that the Safety Variable (X3) has a positive and significant influence on revisit interest (Y2).

8. Hypothesis 8 The Effect of Environment Sustainability (X4) Variables on Revisit Interests (Y2)

The calculated $t$ value of 1.824 is smaller than the $t$ table (1.985) and the significance value (0.071) is more than the $5 \%$ alpha level so that the alternative hypothesis is rejected. So it can be concluded that the Environment Sustainability (X4) variable has a positive influence on revisit interest (Y2) but the effect is not significant.

9. Hypothesis 9 The Effect of Cleanliness Variable (X1) on Revisit Interest (Y2) Through Tourist Satisfaction (Y1)

The results of the path coefficient value of the influence of the Cleanliness variable (X1) on Revisit Interest (Y2) through Tourist Satisfaction (Y1), the coefficient value on the influence of Cleanliness (X1) on Tourist Satisfaction (Y1) is 0.244 and the coefficient value on the influence of Tourist Satisfaction (Y1) on revisit interest (Y2) is 0.321, so the magnitude of the indirect effect of the Cleanliness variable (X1) on revisit interest (Y2) through Tourist Satisfaction (Y1) is $0.244 \mathrm{x}$ $0.321=0.078$. On the other hand, according to the calculation of the statistical value of the Sobel test above, a $\mathrm{Z}$ value of 2,800 is obtained. This value is more than $\mathrm{Z}$ table (1.96) so that hypothesis 9 (H9) is accepted. So it can be concluded that Tourist Satisfaction (Y1) is able to mediate the effect of Cleanliness (X1) on Revisit Interest (Y2). The magnitude of the direct influence of Cleanliness (X1) on Interest in Returning (Y2) is 0.147. However, if Tourist Satisfaction (Y1) is considered as a mediating influence between Cleanliness (X1) on Revisit Interest (Y2), the magnitude of the effect will be $0.147+0.078=0.225$.

10. Hypothesis 10 The Effect of Health Variables (X2) on Revisit Interests (Y2) Through Tourist Satisfaction (Y1)

The results of the path coefficient value of the influence of the Health variable (X2) on Return Interest (Y2) through Tourist Satisfaction (Y1), the coefficient value on the influence of Health (X2) on Tourist Satisfaction (Y1) is 0.219 and the coefficient value on the influence of Tourist Satisfaction (Y1) on interest in revisiting (Y2) is 0.321, so the magnitude of the indirect effect of the Health variable (X2) on interest in revisiting (Y2) through Tourist Satisfaction (Y1) is $0.219 \mathrm{x}$ $0.321=0.070$. Hypothesis testing is carried out using the Sobel test statistic on the basis of the path coefficient graph as follows. Meanwhile, based on the calculation of the statistical value of the Sobel test above, a $\mathrm{Z}$ value of 1.444 was obtained. This value is less than $\mathrm{Z}$ table (1.96) so hypothesis 10 (H10) is rejected. So it can be concluded that Tourist Satisfaction (Y1) has not been able to mediate the effect of Health (X2) on Return Visit Interest (Y2). The magnitude of the direct influence of Health (X2) on interest in revisiting (Y2) is 0.187. However, if Tourist Satisfaction (Y1) is considered as a mediating influence between Health (X2) on Revisit Interest (Y2), the magnitude of the effect will be $0.187+0.070=0.257$.

11. Hypothesis 11 Effect of Safety Variable (X3) on Revisit Interest (Y2) Through Tourist Satisfaction (Y1)

The results of the path coefficient value of the influence of the Safety variable (X3) on Revisit Interest (Y2) through Tourist Satisfaction (Y1), the coefficient value on the influence of Safety (X3) on Tourist Satisfaction (Y1) is 0.224 and the coefficient value on the influence of Tourist Satisfaction (Y1) on interest in revisiting (Y2) of 0.321, so the magnitude 
of the indirect effect of the variable Safety (X3) on interest in revisiting (Y2) through Tourist Satisfaction (Y1) is $0.224 \mathrm{x}$ $0.321=0.072$. Hypothesis testing is carried out using the Sobel test statistic on the basis of the path coefficient graph as follows. Meanwhile, according to the calculation of the statistical value of the Sobel test above, a $\mathrm{Z}$ value of 2.115 was obtained. This value is more than $\mathrm{Z}$ table (1.96) so that hypothesis 11 (H11) is accepted. Previous research by Marpaung (2019) stated that tourist safety did not have a significant direct effect on both tourist satisfaction and interest in revisiting, in contrast to this study, it can be concluded that Tourist Satisfaction (Y1) is able to mediate the effect of Safety (X3) on interest in revisiting (Y2 ). The magnitude of the direct influence between Safety (X3) on Interest in Returning (Y2) is 0.215. However, if Tourist Satisfaction (Y1) is considered as a mediating influence between Safety (X3) on Revisit Interest (Y2), the magnitude of the effect will be $0.224+0.072=0.296$.

12. Hypothesis 12 The Effect of Environment Sustainability (X4) Variables on Revisit Interests (Y2) Through Tourist Satisfaction (Y1)

The results of the path coefficient value of the influence of the Environment Sustainability (X4) variable on Return Interest (Y2) through Tourist Satisfaction (Y1), the coefficient value on the influence of Environment Sustainability (X4) on Tourist Satisfaction (Y1) is 0.270 and the coefficient value on the influence of Tourist Satisfaction ( Y1) on revisit interest (Y2) is 0.321, so the magnitude of the indirect effect of the Environment Sustainability variable (X4) on revisit interest (Y2) through Tourist Satisfaction (Y1) is $0.270 \times 0.321=0.087$. Hypothesis testing is carried out using the Sobel test statistic on the basis of the path coefficient graph as follows. Then based on the calculation of the statistical value of the Sobel test above, the $\mathrm{Z}$ value of 2.653 was obtained. This value is more than $\mathrm{Z}$ table (1.96) so that hypothesis 12 (H12) is accepted. So it can be concluded that Tourist Satisfaction (Y1) is able to mediate the effect of Environment Sustainability (X4) on Revisit Interests (Y2). The amount of direct influence between Environment Sustainability (X4) on Interest in Returning (Y2) is 0.140. However, if Tourist Satisfaction (Y1) is considered as a mediating influence between Environment Sustainability (X4) on Revisit Interest (Y2), the magnitude of the effect will be $0.140+0.087=$ 0.228 .

13. Hypothesis 13 The Effect of Tourist Satisfaction Variable (Y1) on Revisit Interest (Y2)

The results of the test statistic obtained that the $t$-count value of 3.532 is greater than the $t$-table (1.985) and the significance value (0.001) is less than the $5 \%$ alpha level so that the alternative hypothesis is accepted. So it can be concluded that the tourist satisfaction variable (Y1) has a positive and significant influence on revisit interest (Y2).

The discussion based on the data that has been reviewed, it is known that tourists generally realize that cleanliness, health, safety, and environmental sustainability are the most critical and central things in carrying out tourism activities. Meanwhile, Balekambang Beach, which in this study is a popular tourist destination, implements this program correctly and with complete calculation and supervision; this can be seen from the lack of transmission cases or clusters that occur in the Balekambang Beach area. In the results for interest in visiting, it is known that the variables of safety and health have a positive and significant effect on interest in revisiting. However, this is not the case for the variables of cleanliness and environment sustainability which have a positive but not significant effect on interest in revisiting. So based on these results, it can be studied that tourist satisfaction can mediate the influence between safety and health on interest in revisiting and cleanliness and environment sustainability on interest in revisiting with a note that tourist satisfaction must be guaranteed through increased innovation and quality of destinations in implementing CHSE.

Based on previous research, this research is relevant to research according to [10] and [11], who believe that there is a positive influence of the safety variable on tourist satisfaction - traveling and [12] and [11] state a positive influence with the relationship of the Safety variable on interest in revisiting in line with this study. Maintaining and improving security will further motivate them to return to tourist destinations, on the other hand, in line with previous research. According to [11] there is a positive effect of the Health variable on tourist satisfaction; the more healthy indicators show a destination for the tourism destination, the higher tourist satisfaction. Meanwhile, from the aspect of the factors that influence the interest in revisiting, visitors from Balekambang Beach, Malang Regency in implementing CHSE are strongly influenced by how they can adapt to the order and system of setting health protocols, how the coastal environment facilitates CHSE actions, and the presence of unwanted events. Such as disasters and injuries around the Balekambang Beach area.

\section{CONCLUSION}

The conclusion of this journal article is, it is known that the implementation of CHSE in the management of destinations and tourists has a relationship with the concept of revisiting interest and tourist satisfaction, where all components in CHSE are 
positively and significantly related to tourist satisfaction. However, it is known that the safety and health variables have a positive and significant influence on interest in revisiting. However, this is not the case for cleanliness and environment sustainability variables which have a positive but not significant effect on interest in revisiting. The practical implementation of this research, namely, based on the study results, it can be seen that the CHSE instrument can be used as a resolution to start reviving the Balekambang Beach tourism sector, Malang Regency in this Covid-19 pandemic era.

\section{SUGESSTION AND LIMIT}

Suggestions from this study are that managers from other beach destinations around the South Malang area are expected to adopt a similar CHSE. At the same time, the drawback of this study is that it is hoped that in the future, research can also explore the factors that play a role in the management of CHSE.

\section{REFERENCES}

1. Decree of the Minister of Health Number HK.01.07/Menkes/382/2020 concerning Health Protocols for the Community in Public Places and Facilities in the Framework of Prevention and Control of Coronavirus Disease 2019 (Covid-19). Ministry of Health, (2018, September 3)

2. Anderson EW, Fornell C. \& Lehmann DR, 2006, Customer Satisfaction, Market Share, and Profitability: Findings from Sweden. Journal of Marketing, Vol. 58, July, p.53-66

3. Damanik, Janianton and Weber, Helmut F. (2006). Ecotourism Planning. Yogyakarta, Pusbar Ugm \& Andi Yogyakarta

4. Pitana, I Gede and Putu Gede Gayatri. 2005. Sociology of Tourism. Yogyakarta. Andi.

5. Kotler, Philip and Keller, 2007, Marketing Management, Volume I, Twelfth Edition, PT. Index, Jakarta.

6. Djaali, 2011, Educational Psychology, Jakarta: Earth Literacy.

7. Agus Sujanto, 2004 et al, Personality Psychology, (Jakarta: PT Bumi Aksara,)

8. Ali, Hasan. 2013. Marketing and Selected Cases. Yogyakarta. CAPS (Center For Academic Publishing Service) Yogyakarta

9. Amirullah. 2002. Consumer Behavior. First Edition. First Print. Jakarta: Graha Ilmu

10. Poppy Margaretith Nivranti Sondakh. (2016). Service, Security and Attractiveness Affect Tourist Interests Who Visit Natural Tourism Objects of Mount Mahawu, Tomohon. Vol 16, no 1 (2016)

11. S. Soehardi, B Anhar, MH Santoso, S Miranto, R Rusdi.(2021). Satisfaction of International and Domestic Tourists in View of Safety, Health, and Hygiene in Indonesian Tourism Villages, Journal of Scientific Studies 21 (1), 121 -134

12. Zaenal Fanani, Edriana Pangestuti. (2017), Analysis of Security and Comfort of Penanjakan 1 Bromo Tourism Object.Journal of Business Administration. Vol 49, No 2 (2017). 